\title{
Seasonal variation in the net growth rate of the cyanobacterium Cylindrospermopsis raciborskii in a shallow artificial pond in northern Taiwan
}

\author{
Yoshimasa Yamamoto*, Fuh-Kwo Shiah \& Shin-Chieh Hsu \\ Research Center for Environmental Changes, Academia Sinica, 128, Sec. 2, Academia Rd., Taipei 11529, Taiwan
}

Received 8 November 2012; Accepted 25 February 2013

\begin{abstract}
The seasonal dynamics and the net growth rates of the planktonic freshwater cyanobacterium Cylindrospermopsis raciborskii were monitored in a shallow artificial pond in northern Taiwan from February 2010 to January 2011. C. raciborskii was present in the pond throughout the study, and its abundance was positively correlated with water temperature. The net growth rates of $C$. raciborskii displayed no clear seasonal pattern, whereas the highest value $\left(0.184 \mathrm{~d}^{-1}\right)$ was observed in early July when the water temperature sharply increased to the annual highest level. The rapid growth of $C$. raciborskii led to bloom formation, which persisted over the summer months (July and August). Dilution and washout of trichomes by rainfall significantly affected the dynamics of C. raciborskii, including leading to the termination of a bloom.
\end{abstract}

Key words: Cylindrospermopsis raciborskii, net growth rate, rainfall, seasonal dynamics, temperature

\section{Introduction}

The development of cyanobacterial blooms in eutrophic lakes and ponds is an important global water quality issue. Concern exists about increases in the frequency of cyanobacterial blooms as a consequence of global warming, since the growth of bloom-forming species is generally enhanced at high temperatures (Jöhnk et al. 2008, Paerl \& Huisman 2008, 2009, Mehnert et al. 2010). Moreover, global warming may enable tropical species to proliferate at higher latitudes. The expansion of Cylindrospermopsis raciborskii (Woloszynska) Seenayya et Subba Raju in temperate regions is possibly an indication of the synergy between eutrophication and global warming (Paerl \& Huisman 2008). Since C. raciborskii produces toxins that potentially threaten human and livestock (Hawkins et al. 1985, Ohtani et al. 1992, Thomas et al. 1998), its global expansion has attracted substantial attention.

The typical pattern of population dynamics of C. raciborskii in temperate and subtropical regions is to be at a low density or for trichomes to be absent during winter, then, the trichome density starts to increase with an increasing temperature and peaks in summer (Chapman \&

\footnotetext{
*Corresponding author: Yoshimasa Yamamoto; E-mail, yyama@rcec. sinica.edu.tw
}

Schelske 1997, Briand et al. 2002, Hamilton et al. 2005, Burford et al. 2006). This trend reflects the importance of high temperatures in the development of C. raciborskii blooms (Padisák 1997). Experimental results have demonstrated that $C$. raciborskii often exhibits optimal growth at around $30^{\circ} \mathrm{C}$, irrespective of the geographic origin of the strains (Briand et al. 2004, Chonudomkul et al. 2004). Accordingly, optimal growth of $C$. raciborskii in midsummer, rather than its suboptimal growth from spring to early summer, appears to be critical to bloom formation.

Despite the considerable attention paid to the ecophysiology of C. raciborskii, its in situ growth performance has seldom been studied. Monitoring population dynamics together with growth rates would improve our understanding of the mechanisms of bloom formation in C. raciborskii, especially in light of the general importance of growth in determining the abundance of bloom-forming species (e.g. Head et al. 1999, Brunberg \& Blomqvist 2003). In this study, we investigated the seasonal change in the in situ net growth rate of C. raciborskii in a shallow pond in northern Taiwan.

\section{Materials and Methods}

This study was conducted in a concrete pool $\left(110 \mathrm{~m}^{2}\right.$ surface area, $0.3 \mathrm{~m}$ maximum depth) located at $25^{\circ} 02^{\prime} 21^{\prime \prime} \mathrm{N}$ 
and $121^{\circ} 37^{\prime} 02^{\prime \prime} \mathrm{E}$ in Taipei, Taiwan. Water balance of the pond was governed by rainfall and evaporation, as well as excess water outflow through a drain (inner diameter, $60 \mathrm{~mm}$ ), which kept the water level of the pond from exceeding $0.3 \mathrm{~m}$. Large trees by the pond limited the direct sunlight that it received.

The abundance and net growth rates of Cylindrospermopsis raciborskii were determined by seven-day continuous monitoring once or twice monthly from 11 February 2010 to 27 January 2011. Water temperatures at the surface and the bottom were measured using a water quality checker U-52G (Horiba, Kyoto, Japan) at 11:00 a.m. daily during the monitoring periods; the values for the surface and the bottom were averaged for analytical purposes. For enumeration of $C$. raciborskii, $5-\mathrm{mL}$ water samples were collected from three depths, i.e. $0,0.1$ and $0.25 \mathrm{~m}$ (the deepest sampling depth was $0.2 \mathrm{~m}$ in mid-July when the pond depth was $0.24 \mathrm{~m}$ ) using a plastic tube (inner diameter, $6 \mathrm{~mm}$ ) connected to a micropipette, and then fixed with Lugol's iodine solution (1\% final concentration). The density of $C$. raciborskii trichomes was determined under an inverted microscope (Axio Observer A1, Carl Zeiss, Göttingen, Germany) at $\times 200$ magnification; the mean values for three depths were used. A least square linear regression of the natural logarithm of the cyanobacterial trichome density vs. time was performed for each seven-day monitoring period, and the slopes of the regression lines were used as net growth rates of $C$. raciborskii. The net growth rate was considered to be zero when no correlation was found between trichome density and time at a significance level of 0.05 . The trichome densities and water temperatures during each monitoring period were averaged, and then Pearson's correlation coefficient test was performed to analyze the relationships between the density and temperature and between the net growth rate and temperature.

Nutrient concentrations in the surface water were measured once during each seven-day monitoring period. The concentrations of nitrate, nitrite, ammonium and soluble reactive phosphorus (SRP) in the water filtered through a Whatman GF/C filter (Whatman, Kent, UK) were determined using a SP-8001 spectrophotometer (Metertech Inc., Taipei, Taiwan) by the methods of Mullin \& Riley (1955), Bendschneider \& Robinson (1952), Sagi (1966) and Murphy \& Riley (1962), respectively. The total nitrogen (TN) concentration was measured as nitrate under acidic conditions using a spectrophotometer following digestion with alkaline potassium persulfate in an autoclave at $121^{\circ} \mathrm{C}$ for 30 min (Crumpton et al. 1992). The total phosphorus (TP) concentration was measured as SRP spectrophotometrically following digestion with potassium persulfate in an autoclave at $121^{\circ} \mathrm{C}$ for $30 \mathrm{~min}$, by using the method of Murphy \& Riley (1962).

Daily precipitation was sampled with a homemade sixchannel automatic rain collector on the building rooftop ( $\sim 20 \mathrm{~m}$ high) of the Institute of Earth Science of Academia Sinica, which is located $330 \mathrm{~m}$ away from the study pond. The sampled rainwater was immediately filtered through a polycarbonate membrane with a pore size of 0.45 $\mu \mathrm{m}$ and a diameter of $47 \mathrm{~mm}$ (Nuclepore Track-Etched Membranes, Whatman, Kent, UK) by using plastic filtration units (Nalgene Filterware 300-4100, Techmate, Milton Keynes, UK). An aliquot of filtered water was subjected to chemical analyses of ionic composition, including $\mathrm{NH}_{4}^{+}$and $\mathrm{NO}_{3}^{-}$, with an ion chromatograph (Dionex ICS - 90 and ICS - 1500, Thermo Scientific Dionex, California, USA) (Hsu et al. 2007). The collected rain volume was converted into the corresponding amount of precipitation by dividing it by the area $\left(0.0919 \mathrm{~m}^{2}\right)$ of the receiving funnel. The rain sensor occasionally failed because the lid did not open successfully, and the rain sample was subsequently lost. When the sampling failed, the precipitation data measured at a nearby weather-monitoring site (JiuZhuang Elementary School), located $230 \mathrm{~m}$ away from the study pond, were used. The inorganic nitrogen flux was calculated as the sum of ammonium and nitrate fluxes.

\section{Results}

Figure 1 shows the daily rainfall and nitrogen flux from February 2010 to January 2011. The amount of annual rainfall was $2231 \mathrm{~mm}$, with the highest monthly rainfall in June $(408 \mathrm{~mm})$ and the second highest in October $(367 \mathrm{~mm})$. No clear seasonal pattern was observed in nitrogen flux.

Water temperature increased from February to the maximum in early July (mean $28.8^{\circ} \mathrm{C}$ ), before decreasing to the

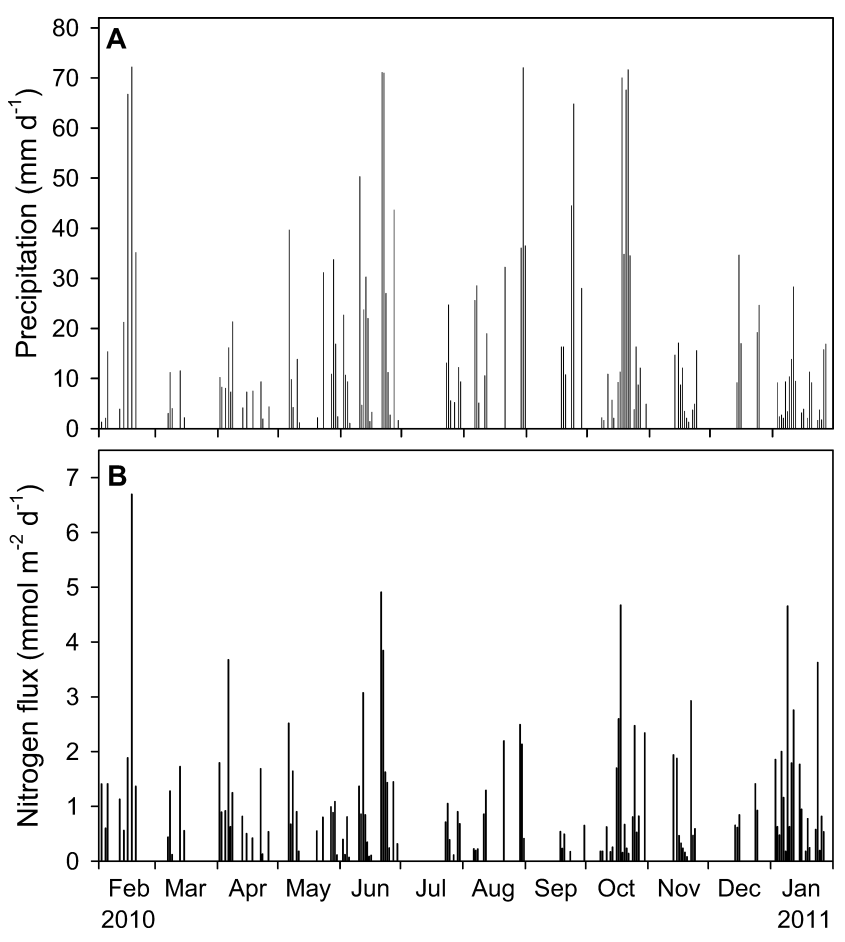

Fig. 1. Variations in daily precipitation (A) and nitrogen flux (B) in northern Taiwan from February 2010 to January 2011. 


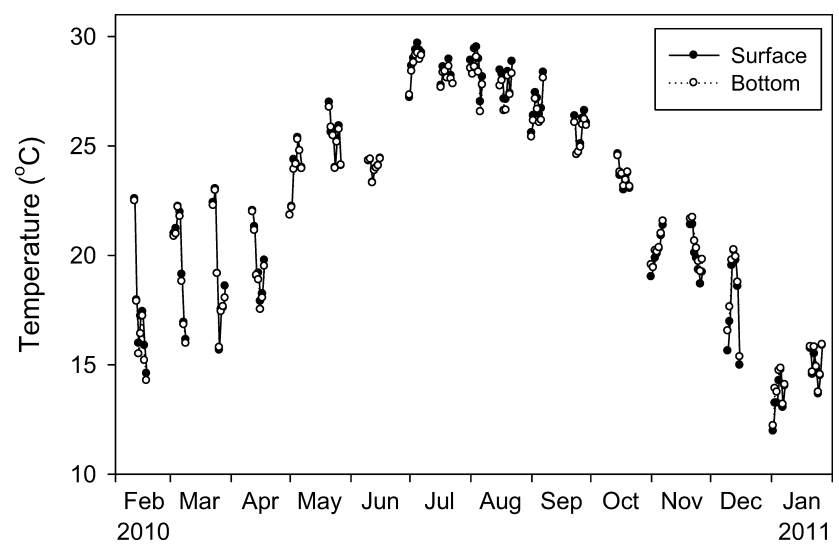

Fig. 2. Variation in water temperatures measured at the surface and the bottom of the study pond from February 2010 to January 2011.

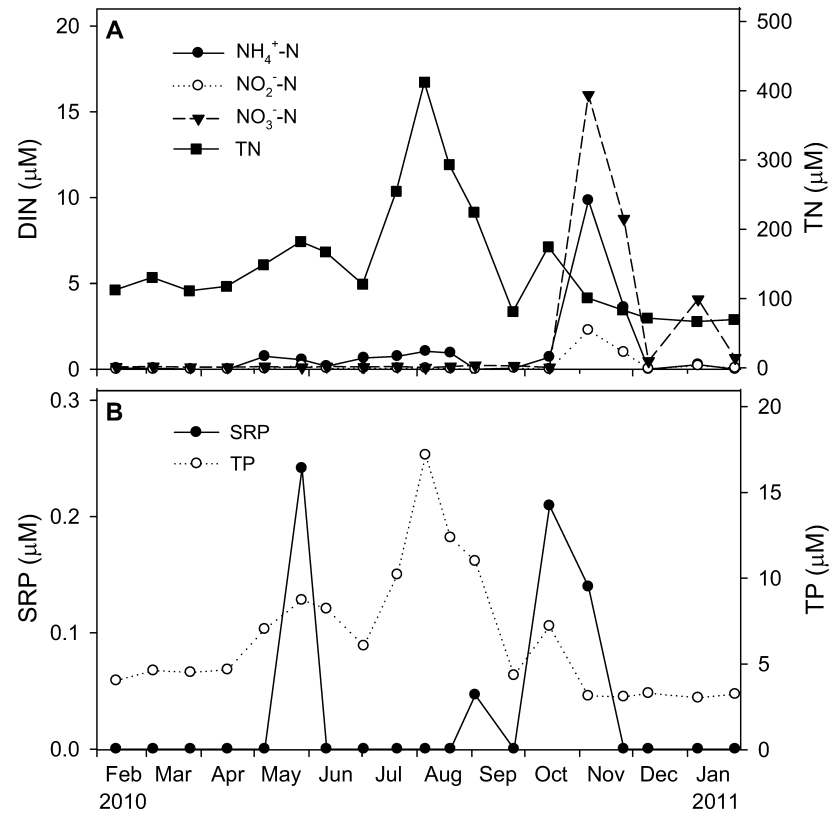

Fig. 3. Variations in concentrations of nitrogen (A) and phosphorus (B) in the study pond from February 2010 to January 2011. DIN denotes dissolved inorganic nitrogen, which includes ammonium $\left(\mathrm{NH}_{4}^{+}-\mathrm{N}\right)$, nitrite $\left(\mathrm{NO}_{2}^{-}-\mathrm{N}\right)$ and nitrate $\left(\mathrm{NO}_{3}^{-}-\mathrm{N}\right)$. $\mathrm{SRP}, \mathrm{TN}$ and TP denote soluble reactive phosphorus, total nitrogen and total phosphorus, respectively.

minimum in early January (mean $13.7^{\circ} \mathrm{C}$ ) (Fig. 2). The temperature difference between the surface and the bottom was within $0.92^{\circ} \mathrm{C}$. The surface temperature often exceeded the bottom temperature from February to September, whereas the bottom temperature tended to exceed the surface temperature from October to January.

No clear seasonal patterns were observed in the concentrations of dissolved inorganic nitrogen and SRP (Fig. 3). The concentrations of ammonium, nitrite and nitrate peaked in early November. The SRP concentration was

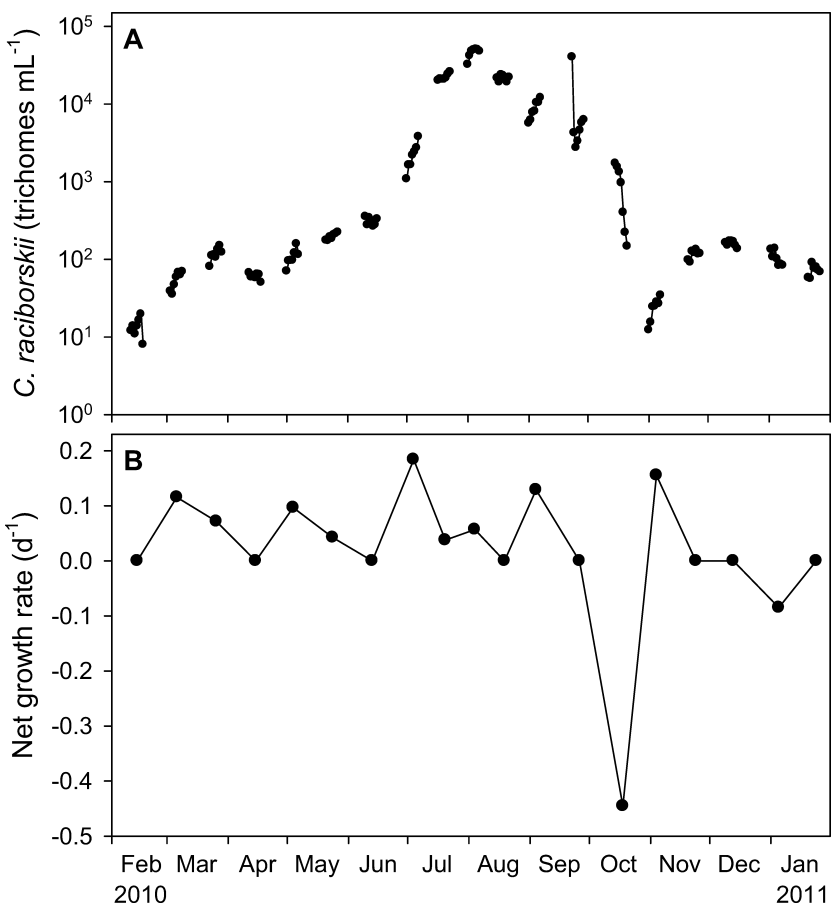

Fig. 4. Variations in abundance (A) and net growth rate (B) of Cylindrospermopsis raciborskii in the study pond from February 2010 to January 2011.

low and often under the detection limit. The total nitrogen (TN) and total phosphorus (TP) concentrations greatly exceeded those of dissolved forms, peaking in early August. A significant positive correlation existed between TN and TP concentrations $(n=9, r=0.981, p<0.001)$.

Cylindrospermopsis raciborskii was present during the course of the study, and was distributed almost evenly in the water column (Fig. 4). The trichome density of C. raciborskii tended to increase from February to June. In early July, the trichome density of $C$. raciborskii increased rapidly at a rate of $0.184 \mathrm{~d}^{-1}$, soon forming a bloom in midJuly. Its trichome density continuously increased in early August and reached the maximum of $5.06 \times 10^{4}$ trichomes $\mathrm{mL}^{-1}$ on 5 August. Although the trichome density decreased rapidly at a rate of $-0.445 \mathrm{~d}^{-1}$ in October, it increased again in early November. No increase in the trichome density occurred after late November. The natural logarithm of the trichome density was significantly correlated positively with water temperature $(n=19, r=0.815$, $p<0.001$ ) (Fig. 5). The net growth rates of C. raciborskii showed no clear seasonal pattern, and, thus, exhibited an insignificant correlation with water temperature $(n=19$, $r=0.103, p=0.67$ ).

\section{Discussion}

The pond was clearly eutrophic based on the concentrations of total nitrogen and total phosphorus. However, the concentrations of dissolved inorganic nitrogen and soluble 


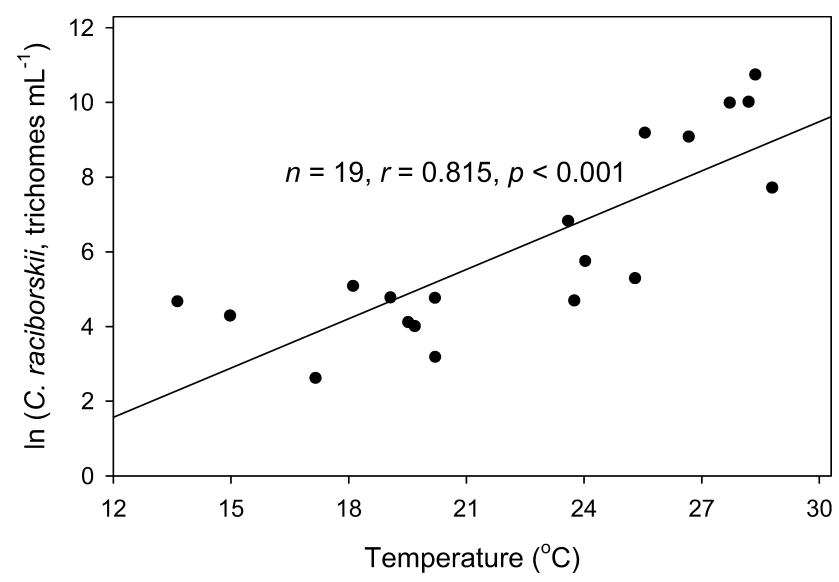

Fig. 5. Relationship between trichome density of Cylindrospermopsis raciborskii and water temperature.

reactive phosphorus (SRP) were often low or at undetectable levels. Under such conditions, dissolved inorganic nitrogen and SRP may act as limiting factors for the growth of phytoplankton, including Cylindrospermopsis raciborskii. Heterocyte formation in C. raciborskii in the pond was enhanced during the growing season (Yamamoto \& Shiah 2012), implying that nitrogen indeed becomes a limiting factor for the growth of $C$. raciborskii in summer, suggesting that nitrogen fixation should play an important role in alleviating the nitrogen depletion. Under nitrogendepleted conditions, the deposition of nitrogen through rainfall seems to benefit the growth of $C$. raciborskii. The nitrogen derived from rainfall in late June might have contributed at least partially to the massive growth of the cyanobacterium in early July. In contrast, heterocyte density of $C$. raciborskii fell in autumn when the concentrations of dissolved inorganic nitrogen in the pond were relatively high (Yamamoto \& Shiah 2012). Therefore, nitrogen input through rainfall apparently does not benefit $C$. raciborskii in autumn when its growth is not limited by nitrogen. Given the high phosphorus-storage capacity of phytoplankton (Cotner \& Wetzel 1992) and the fact that cyanobacteria and/or green algae were abundant in the study pond all year round (Yamamoto \& Shiah 2012), the extremely low SRP concentration in the pond appears to be largely owing to their uptake. Superior phosphorus uptake ability of $C$. raciborskii (Isvánovics et al. 2000) may be responsible for its successful growth and bloom formation under low SRP concentrations (Burford et al. 2006, Kenesi et al. 2009).

This study showed that water temperature had a more direct influence on the seasonal dynamics of $C$. raciborskii than did the nutrient concentrations. The positive correlation between $C$. raciborskii abundance and water temperature suggests the preference of this species for high temperatures, which is consistent with the findings of previous studies (Padisák 1997, Saker \& Griffiths 2001, MoustakaGouni et al. 2007). We can thus infer that the rapid eleva- tion of water temperature to the optimal range for its growth triggered the development of the C. raciborskii bloom in July.

Water temperatures in the pond were always above $15^{\circ} \mathrm{C}$, except in February 2010 and January 2011. Given that the threshold temperature for the growth of $\mathrm{C}$. raciborskii is generally between 10 and $15^{\circ} \mathrm{C}$ (Chonudomkul et al. 2004), water temperatures in the study pond in February 2010 and January 2011 might have been too low for the growth of $C$. raciborskii, explaining why the cyanobacterium failed to grow in those months. Conversely, since the water temperatures from March to December 2010 were mostly above the threshold for the growth of C. raciborskii, the thermal conditions in the study pond during this period were likely within the range that allows $C$. raciborskii to grow. Nevertheless, C. raciborskii frequently did not exhibit significant increase in abundance during this period. The net growth rate used herein should be viewed as the difference between the actual growth rate of the cyanobacterium and the disappearance rate attributed to loss processes (Reynolds 1984). Thus, insignificant population change during a potentially favorable period for growth suggests that some loss processes cancelled the actual growth of the cyanobacterium.

Ahn et al. (2002) observed washout of cyanobacteria in the Daechung Reservoir of South Korea owing to heavy rainfall and their rapid recovery after the rainfall. A similar phenomenon occurred in the late stage of the C. raciborskii bloom in early and late September. In both periods, no rainfall was recorded for several days after the rainfallinduced washout of $C$. raciborskii trichomes, and water temperatures remained high $\left(>25^{\circ} \mathrm{C}\right)$. Such environmental conditions of a stable water column and high temperature favor the massive growth of C. raciborskii (Padisák 1997, Saker \& Griffiths 2001, Berger et al. 2006), and, therefore, would have facilitated cyanobacterial recovery. In contrast, the prolonged heavy rainfalls in mid-October rapidly flushed out C. raciborskii trichomes, subsequently terminating the bloom. The water temperatures in mid-October $\left(23.1-24.6^{\circ} \mathrm{C}\right)$ were slightly below the optimal range for the development of C. raciborskii blooms (Padisák 1997), and trended downward. Given that $C$. raciborskii in the study pond forms a bloom by rapid growth at high temperatures, the deteriorating temperature condition was also likely responsible, at least partially, for the termination of the bloom.

Rainfall-induced dilution and washout had a significant direct influence not only on bloom collapse, but also on temporary declines in the C. raciborskii trichome density in the study pond. The water temperature steadily increased from February to July. Since laboratory experiments have revealed that increasing temperatures activate the growth of $C$. raciborskii (Briand et al. 2004, Chonudomkul et al. 2004), the temperature conditions during this period became increasingly favorable for the growth of $C$. raciborskii. However, frequent rainfalls during this period 
often prevented the increase of $C$. raciborskii trichome density. The decrease in the trichome density of $C$. raciborskii from late March to mid-April may be attributable to dilution and washout by the rain that fell between the periodic monitoring. Why $C$. raciborskii failed to grow in mid-April remains unclear, though the dominance of the green alga Pediastrum duplex (Meyen) during this period (Yamamoto \& Shiah 2012) might have prevented the growth of $C$. raciborskii, given the low competitiveness of C. raciborskii (Briand et al. 2002). Rainfall during the periods of monitoring in May and June directly reduced $C$. raciborskii trichome density, subsequently lowering net growth rates. Low net growth rates of $C$. raciborskii from mid-July to mid-August might be because the carrying capacity of the study pond was reached as a result of bloom formation. However, possible declines in trichome densities owing to dilution or washout can still not be ruled out, given the frequent rainfall during this period. Although rainfall in mid-October caused the $C$. raciborskii bloom to collapse, the cyanobacterial trichome density recovered slightly in November. The water temperatures in early November $\left(19.3-21.5^{\circ} \mathrm{C}\right)$ were barely within the range for the suboptimal growth of $C$. raciborskii (Chonudomkul et al. 2004) and increased continuously during the monitoring. Moreover, the lack of a rainfall in this period might have left the water column stable. Such conditions are assumed to have enabled $C$. raciborskii to grow steadily.

In conclusion, water temperature crucially regulated the abundance of $C$. raciborskii in the study pond. Cylindrospermopsis raciborskii formed a bloom soon after the water temperature reached the optimal range for its growth. Heavy rainfalls can rapidly reduce the trichome density of $C$. raciborskii through dilution and washout. Even though rainfalls in spring and summer reduced the trichome density of $C$. raciborskii, it soon recovered to the pre-rain levels since the temperature conditions in these seasons often favored the growth of the cyanobacterium. Conversely, washout due to heavy rainfalls and the falling temperature in autumn were critical to the termination of the $C$. raciborskii bloom.

\section{Acknowledgments}

We would like to thank Mr. Ted Knoy of Yuanpei University for revising the English in this manuscript.

\section{References}

Ahn CY, Chung AS, Oh HM (2002) Rainfall, phycocyanin, and $\mathrm{N}: \mathrm{P}$ ratios related to cyanobacterial blooms in a Korean large reservoir. Hydrobiologia 474: 117-124.

Bendschneider K, Robinson RJ (1952) A new spectrophotometric method for the determination of nitrite in sea water. J Mar Res 11: 87-96.

Berger C, Ba N, Gugger M, Bouvy M, Rusconi F, Couté A, Troussellier M, Bernard C (2006) Seasonal dynamics and tox- icity of Cylindrospermopsis raciborskii in Lake Guiers (Senegal, West Africa). FEMS Microbiol Ecol 57: 355-366.

Briand JF, Robillot C, Quiblier-Llobéras C, Humbert JF, Couté A, Bernard C (2002) Environmental context of Cylindrospermopsis raciborskii (Cyanobacteria) blooms in a shallow pond in France. Water Res 36: 3183-3192.

Briand JF, Leboulanger C, Humbert JF, Bernard C, Dufour P (2004) Cylindrospermopsis raciborskii (Cyanobacteria) invasion at mid-latitudes: selection, wide physiological tolerance, or global warming? J Phycol 40: 231-238.

Brunberg AK, Blomqvist P (2003) Recruitment of Microcystis (Cyanophyceae) from lake sediments: the importance of littoral inocula. J Phycol 39: 58-63.

Burford MA, McNeale KL, McKenzie-Smith FA (2006) The role of nitrogen in promoting the toxic cyanophyte Cylindrospermopsis raciborskii in a subtropical water reservoir. Freshw Biol 51: 2143-2153.

Chapman AD, Schelske CL (1997) Recent appearance of Cylindrospermopsis (Cyanobacteria) in five hypereutrophic Florida lakes. J Phycol 33: 191-195.

Chonudomkul D, Yongmanitchai W, Theeragool G, Kawachi M, Kasai F, Kaya K, Watanabe MM (2004) Morphology, genetic diversity, temperature tolerance and toxicity of Cylindrospermopsis raciborskii (Nostocales, Cyanobacteria) strains from Thailand and Japan. FEMS Microbiol Ecol 48: 345-355.

Cotner JB Jr, Wetzel RG (1992) Uptake of dissolved inorganic and organic phosphorus compounds by phytoplankton and bacterioplankton. Limnol Oceanogr 37: 232-243.

Crumpton WG, Isenhart TM, Mitchell PD (1992) Nitrate and organic $\mathrm{N}$ analyses with second-derivative spectroscopy. Limnol Oceanogr 37: 907-913.

Hamilton PB, Ley LM, Dean S, Pick FR (2005) The occurrence of the cyanobacterium Cylindrospermopsis raciborskii in Constance Lake: an exotic cyanoprokaryote new to Canada. Phycologia 44: 17-25.

Hawkins PR, Runnegar MTC, Jackson ARB, Falconer IR (1985) Severe hepatotoxicity caused by the tropical cyanobacterium (blue-green alga) Cylindrospermopsis raciborskii (Woloszynska) Seenaya and Subba Raju isolated from a domestic water supply reservoir. Appl Environ Microbiol 50: 1292-1295.

Head RM, Jones RI, Bailey-Watts AE (1999) An assessment of the influence of recruitment from the sediment on the development of planktonic populations of cyanobacteria in a temperate mesotrophic lake. Freshw Biol 41: 759-769.

Hsu SC, Liu SC, Kao SJ, Jeng WL, Huang YT, Tseng CM, Tsai F, Tu JY, Yang Y (2007) Water-soluble species in the marine aerosol from the northern South China Sea: High chloride depletion related to air pollution. J Geophys Res 112: D19304.

Isvánovics V, Shafik HM, Présing M, Juhos S (2000) Growth and phosphate uptake kinetics of the cyanobacterium, Cylindrospermopsis raciborskii (Cyanophyceae) in throughflow cultures. Freshw Biol 43: 257-275.

Jöhnk KD, Huisman J, Sharples J, Sommeijer B, Visser PM, Stroom JM (2008) Summer heatwaves promotes blooms of harmful cyanobacteria. Glob Change Biol 14: 495-512.

Kenesi G, Shafik HM, Kovács AW, Herodek S, Présing M (2009) Effect of nitrogen forms on growth, cell composition and $\mathrm{N}_{2}$ fixation of Cylindrospermopsis raciborskii in phosphorus- 
limited chemostat cultures. Hydrobiologia 623: 191-202.

Mehnert G, Leunert F, Cirés S, Jöhnk KD, Rücker J, Nixdorf B, Wiedner C (2010) Competitiveness of invasive and native cyanobacteria from temperate freshwater under various light and temperature conditions. J Plankton Res 32: 1009-1021.

Moustaka-Gouni M, Vardaka E, Tryfon E (2007) Phytoplankton species succession in a shallow Mediterranean lake (L. Kastoria, Greece): steady-state dominance of Limnothrix redekei, Microcystis aeruginosa and Cylindrospermopsis raciborskii. Hydrobiologia 575: 129-140.

Mullin JB, Riley JP (1955) The spectrophotometric determination of nitrate in natural waters, with particular reference to sea-water. Anal Chim Acta 12: 464-480.

Murphy J, Riley JP (1962) A modified single solution method for the determination of phosphate in natural waters. Anal Chim Acta 27: 31-36.

Ohtani I, Moore RE, Runnegar MTC (1992) Cylindrospermopsin: a potent hepatotoxin from the blue-green alga Cylindrospermopsis raciborskii. J Am Chem Soc 114: 7941-7942.

Padisák J (1997) Cylindrospermopsis raciborskii (Woloszynska) Seenayya et Subba Raju, an expanding, highly adaptive cyanobacterium: worldwide distribution and review of its ecology.
Arch Hydrobiol/Suppl 107: 563-593.

Paerl HW, Huisman J (2008) Blooms like it hot. Science 320: 5758.

Paerl HW, Huisman J (2009) Climate change: a catalyst for global expansion of harmful cyanobacterial blooms. Environ Microbiol Rep 1: 27-37.

Reynolds CS (1984) The Ecology of Freshwater Phytoplankton. Cambridge University Press, Cambridge, 384 pp.

Sagi T (1966) Determination of ammonia in sea water by the indophenol method and its application to the coastal and off-shore waters. Oceanogr Mag 18: 43-51.

Saker ML, Griffiths DJ (2001) Occurrence of blooms of the cyanobacterium Cylindrospermopsis raciborskii (Woloszyńska) Seenayya and Subba Raju in a north Queensland domestic water supply. Mar Freshw Res 52: 907-915.

Thomas AD, Saker ML, Norton JH, Olsen RD (1998) Cyanobacterium Cylindrospermopsis raciborskii as a probable cause of death in cattle in northern Queensland. Aust Vet J 76: 592594.

Yamamoto Y, Shiah FK (2012) Factors related to the dominance of Cylindrospermopsis raciborskii (cyanobacteria) in a shallow pond in northern Taiwan. J Phycol 48: 984-991. 